\title{
Study of Rapid Visual Screening of Buildings for High Potential Seismic Hazard According to Indonesian Standard
}

\author{
Endah Wahyuni ${ }^{1}$, Pujo Aji ${ }^{1}$, Data Iranata ${ }^{1}$, and Firman Budiman ${ }^{1}$
}

\begin{abstract}
This paper presents a study of Rapid Visual Screening (RVS) using FEMA 154 and applied in Indonesia based on SNI 1726. RVS is a method to asses potential earthquake hazard of a building based on visual observation ("sidewalk survey") of the exterior and interior building if possible, and a Data Collection Form. This study is intended to see how important the RVS of the FEMA 154 can be implemented in Indonesia with a case study at Yogyakarta. The buildings that reviewed were assumed to have the same parameters as mention in FEMA 154 and compatible with SNI 1726 (Indonesian earthquake map). The results from field survey were compared to the numerical analysis. From the case study, it was found that the administration building of ATK Academy, the dormitory building of Ministry of Internal Affairs, the office building of Department of Agriculture, and the educational building of Health Polytechnics have a score more than 2, and the buildings are also declared safe according to SNI 1726.
\end{abstract}

Keywords-Rapid Visual Screening, FEMA 154, High Seismicity, Earthquake

\section{INTRODUCTION}

This paper presented a study of an application and modification of RVS [1] with an overview of the Indonesian Earthquake Map according to SNI 1726 [2]. RVS is a quick method to analyse buildings for potential earthquake hazard based on visual survey $[3,4]$. The Data Collection Form of RVS on FEMA 154 includes space for documenting building, identification information, including its use and size, a photograph of the building, sketches, and documentation of pertinent data related to seismic performance. The Data Collection Form is included to identify the primary structural lateralload-resisting system and the structural materials of the building. Thus this method could be considered as a guidance on a building assessment system for seismic vulnerability in accordance with existing regulation in Indonesia.

The main purpose of this study is to use the RVS and applied to SNI 1726 for assessing the building seismic vulnerability. Detailed purposes of this study are:

1. Understanding building seismic vulnerability assessment based on FEMA 154.

2. Understanding how to apply RVS from FEMA 154 to SNI 1726.

3. Apply a case study of the buildings in Yogyakarta. Present the material simply and concisely.

\section{RESEARCH METHODS}

The method of this study can be described as follows:
1. To analysis the earthquake zone based on FEMA 154 [1] and to be compared with SNI 1726 [2]. The inputs RVS form were compared with Indonesian standard of SNI 1726.

2. Pre-field Data Collection

The case study is the buildings in a high seismic area (Yogyakarta) that distinguished based on its function, which are the Administration building of ATK academy; the Dormitory building of Ministry of Internal Affair; the Office building of Department of Agriculture; the Educational building of Polytechnics of Health.

3. FEMA 154 Analysis - Field Study

The data from pre-field data collecting will be analysed and recorded for field survey. Then prepare every needs for RVS data collecting to make the field data collecting and analysis of the reviewed building became easier. The data is collected to get the information and the final score of each building.

4. Numerical Analysis

The buildings were modelled and analysed using software - SAP2000. The results were used to control of building structure, which satisfied or not based on SNI 1726.

5. Comparison Field Study and Numerical Analysis After field study and numerical analysis, the final score using FEMA 154 and the analysis using SAP2000 are compared. It is needed to find out the both methods have the same conclusion or not.

\section{RESEARCH RESULT}

\section{A. Analysis of the scores in RVS's for}

The score in FEMA 154 is analysed to find out what host influential values for every type of building structures. This analysis is compared between the Basic Score of the structure and the other score, thus this analysis can be useful as reference during field survey. The Basic Structural Hazard Scores for various building types are provided on the form. The Basic Score, Score Modifiers, and final Structural Score, S, all relate to the probability of building collapse, should severe ground shaking occur. Final S scores typically range from 0 to 7 , with higher $\mathrm{S}$ scores corresponding to better expected seismic performance. An S score of 2 is suggested as a "cut-off", based on present seismic design criteria. Using this cutoff level, buildings having an S score of 2 or less should be investigated by a design professional experienced in seismic design. 
TABLE 1.

COMPARISON OF MODIFIER SCORES TO BASIC SCORE

\begin{tabular}{|l|c|c|c|c|c|c|}
\hline \multicolumn{1}{|c}{ BUILDING TYPE } & \multicolumn{2}{c|}{ W2 } & \multicolumn{2}{c|}{ S2 } & \multicolumn{2}{c|}{ C1 } \\
\cline { 2 - 7 } & Wood & $\%$ & (BR) & \% & (MRF) & $\%$ \\
\hline Basic Score & 3.8 & & 3.0 & & 2.5 & \\
Mid Rise (4 to 7 Stories) & N/A & N/A & 0.4 & 13.3 & 0.4 & 16.0 \\
High Rise (>7 stories) & N/A & N/A & 0.8 & 26.7 & 0.6 & 24.0 \\
Vertical Irregularity & -2.0 & 52.6 & -1.5 & -50.0 & -1.5 & -60.0 \\
Plan Irregularity & -0.5 & 13.2 & -0.5 & -16.7 & -0.5 & -20.0 \\
Pre-Code & -1.0 & 26.3 & -0.8 & -26.7 & -1.2 & -48.0 \\
Post-Benchmark & 1.4 & -36.8 & 1.4 & 46.7 & 1.4 & 56.0 \\
\hline Soil Type C & -0.4 & -10.5 & -0.4 & -13.3 & -0.4 & -16.0 \\
Soil Type D & -0.8 & 21.1 & -0.6 & -20.0 & -0.6 & -24.0 \\
Soil Type E & -0.8 & 21.1 & -1.2 & -40.0 & -1.2 & -48.0 \\
\hline
\end{tabular}

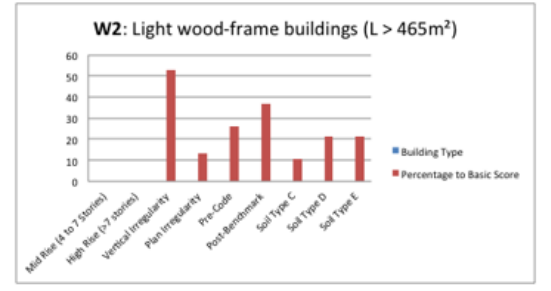

(a) Light wood-frame Building (W2)

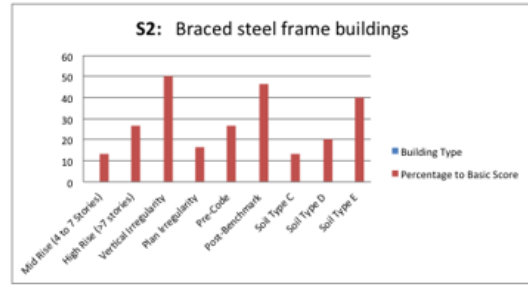

(b) Braced steel frame buildings (S2)

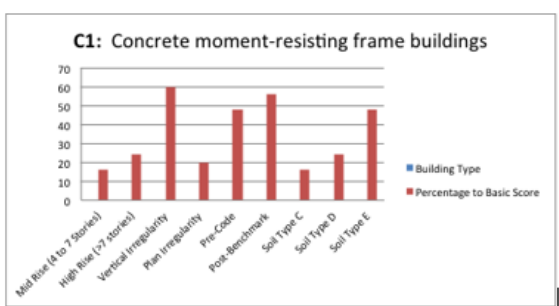

(c) Concrete moment-resisting frame (C1)

Figure 1. Comparison of Modifier to Basic scores

There are fifteen structural types related to the basic score, i.e. wood, steel, concrete and masonry. The modifier scores related to the stories, the vertical and horizontal irregularities, pre-code, post-benchmark and soil types. The percentage of the modifier score comparing to the basic score of each structural types is shown in Figure 1. The figure is an example for the structural type of W2 (Light wood-frame buildings), S2 (Braced steel frame buildings) and C1 (concrete moment resisting frame buildings). How to calculate the score can be seen in Table 1.

As shown in Table 1 and Figure 1, the modifier scores that must be noted are the post-benchmark and the vertical irregularity because the both scores influence more on the final score.

\section{B. Determination of Earthquake Area}

To determinate the earthquake area and the selected form in this case are based on:

1. Spectral response period 0.2 second and 1 second based on SNI 1726.

2. Spectral response acceleration based on FEMA 154.

After every spectral response of the earthquake from FEMA 154 applied to SNI 1726, a mapping of the earthquake area can be seen in Figure 2 for 0.2 second and 1.0 second.

After determining the survey location, which is Yogyakarta, based on the SNI 1726, the response acceleration of the earthquake is $1.283 \mathrm{~g}$ for 0.2 second period, and $0.465 \mathrm{~g}$ for 1 second period. Thus it can be determined that the High Seismicity form is used to analysis of the buildings.

\section{Field study of FEMA 154}

Before starting field study, the pre-field data collection should be done, including review of existing building files and databases to document information identifying buildings to be screened (e.g., address, number of stories, design date) and identifying soil types for the survey area. Field screening of individual buildings, which consists of:

1. Verifying and updating building identification information,

2. Walking around the building and sketching a plan and elevation view on the Data Collection Form,

3. Determining occupancy (that is, the building use and number of occupants),

4. Determining soil type, if not identified during the pre-planning process,

5. Identifying potential non-structural falling hazards,

6. Identifying the seismic-lateral-load resisting system (entering the building, if possible, to facilitate this process) and circling the Basic Structural Hazard Score on the Data Collection Form,

7. Identifying and circling the appropriate seismic performance attribute Score Modifiers (e.g., number of stories, design date, and soil type) on the Data Collection Form,

8. Determining the Final Score, S (by adjusting the Basic Structural Hazard Score with the Score Modifiers identified in Step 7), and deciding if a detailed evaluation is required, and

9. Photographing the building. 
TABLE 2.

RVS FORM OF ATK ACADEMY BUILDINGS

\begin{tabular}{|c|c|c|c|c|c|c|c|c|c|c|c|c|c|c|c|c|}
\hline \multirow[b]{2}{*}{$\begin{array}{l}\text { Assembly } \\
\text { Commercial } \\
\text { Emer. Services }\end{array}$} & \multicolumn{3}{|c|}{ OCCUPANCY } & \multicolumn{3}{|c|}{ SOIL } & \multicolumn{4}{|c|}{ TYPE } & \multicolumn{6}{|c|}{ FALLING HAZARDS } \\
\hline & \multirow[t]{2}{*}{$\begin{array}{l}\text { Govt } \\
\text { Historic } \\
\text { Industrial }\end{array}$} & \multicolumn{2}{|c|}{$\begin{array}{l}\text { Office } \\
\text { Residential } \\
\text { School }\end{array}$} & \multicolumn{3}{|c|}{\begin{tabular}{ll}
\multicolumn{2}{c}{ Number of Persons } \\
$0-10$ & $11-100$ \\
$101-1000$ & $1000+$
\end{tabular}} & \multicolumn{2}{|c|}{$\begin{array}{ccc}\text { A } & \text { B } & \text { C } \\
\text { Hard } & \text { Avg. } & \text { Dense } \\
\text { Rock } & \text { Rock } & \text { Soil }\end{array}$} & $\begin{array}{l}\mathrm{D} \\
\text { Stiff } \\
\text { Soil }\end{array}$ & $\begin{array}{cc}E & F \\
\text { Soft } & \text { Poor } \\
\text { Soil } & \text { Soil }\end{array}$ & \multicolumn{2}{|c|}{$\begin{array}{l}\square \\
\text { Unreinforced } \\
\text { Chimneys }\end{array}$} & $\underset{\text { Parapets }}{\square}$ & \multicolumn{2}{|c|}{$\square_{\text {Cladding }}$} & $\begin{array}{l}\square \\
\text { Other: }\end{array}$ \\
\hline \multicolumn{16}{|c|}{ BASIC SCORE, MODIFIERS, AND FINAL SCORE, $S$} & \\
\hline$\overline{\text { BUILDING } 1}$ & $\overline{\mathrm{YPE}}$ & W1 & W2 & $\begin{array}{c}\text { S1 } \\
\text { (MRF) }\end{array}$ & $\begin{array}{l}\text { S2 } \\
\text { (BR) }\end{array}$ & $\begin{array}{l}\mathrm{S3} \\
(\mathrm{LM})\end{array}$ & $\begin{array}{c}\mathrm{S} 4 \\
(\mathrm{RCS})\end{array}$ & $\begin{array}{c}\text { S5 } \\
\text { (URM INF) }\end{array}$ & $\begin{array}{c}\mathrm{C1} \\
\text { (MRF) }\end{array}$ & $\begin{array}{l}\mathrm{C2} \\
\text { (SW) }\end{array}$ & $\begin{array}{c}\text { C3 } \\
\text { (URM INF) }\end{array}$ & $\begin{array}{l}\mathrm{PC1} \\
\text { (TU) }\end{array}$ & PC2 & $\begin{array}{l}\text { RM1 } \\
(\mathrm{FD})\end{array}$ & $\begin{array}{l}\text { RM22 } \\
\text { (RD) }\end{array}$ & $\overline{\text { URI }}$ \\
\hline asic Sc & & 4. & & 2.8 & 3.0 & 3. & 2.8 & 2.0 & 2.5 & 2.8 & 1. & 2.6 & 2.4 & 2.8 & 2.8 & 1.8 \\
\hline lid Rise & stories) & $\mathrm{N} /$ & $\mathrm{N} / \mathrm{A}$ & +0.2 & +0.4 & N/A & +0.4 & +0.4 & +0.4 & +0.4 & +0.2 & $\mathrm{~N} /$ & +0.2 & +0.4 & +0.4 & 0.0 \\
\hline ligh Rise & ories) & N/A & $\mathrm{N} / \mathrm{t}$ & +0.6 & +0.8 & N/A & +0.8 & +0.8 & +0.6 & +0.8 & +0.3 & N/A & +0.4 & VIA & +0.6 & $\mathrm{~N} / t$ \\
\hline ertical Irre & & -2 & -2.0 & -1.0 & -1.5 & IA & -1.0 & -1.0 & -1.5 & -1.0 & -1.0 & $\mathrm{~N} /$ & -1.0 & 1.0 & -1.0 & -1 . \\
\hline lan irregula & & -0 . & -0.5 & -0.5 & -0.5 & -0.5 & -0.5 & -0.5 & -0.5 & -0.5 & 0.5 & -0.5 & -0.5 & 0.5 & -0.5 & -0. \\
\hline re-Code & & 0. & -1 . & -1.0 & -0.8 & -0.6 & -0.8 & -0.2 & -1.2 & -1.0 & -0.2 & -0 & -0.8 & -1.0 & -0.8 & -0 . \\
\hline Post-Bench & & +2.4 & +2.4 & +1.4 & +1.4 & N/A & +1.6 & N/A & +1.4 & +2.4 & $N / A$ & +2.4 & $N / A$ & +2.8 & +2.6 & $N / A$ \\
\hline oil Typ & & 0.0 & -0 & -0.4 & -0.4 & -0.4 & -0.4 & -0.4 & -0.4 & -0.4 & -0. & -0.4 & -0.4 & -0.4 & -0.4 & -0.4 \\
\hline il $T$ & & 0. & -0 & -0 & -0 & -0.6 & -0. & -0.4 & -0.6 & -0.6 & -0.4 & -0 & -0.6 & -0.6 & -0.6 & -0.6 \\
\hline Soil Type E & & 0.0 & -0.8 & -1.2 & -1.2 & -1.0 & -1.2 & -0.8 & -1.2 & -0.8 & -0.8 & -0.4 & -1.2 & -0.4 & -0.6 & -0.8 \\
\hline
\end{tabular}

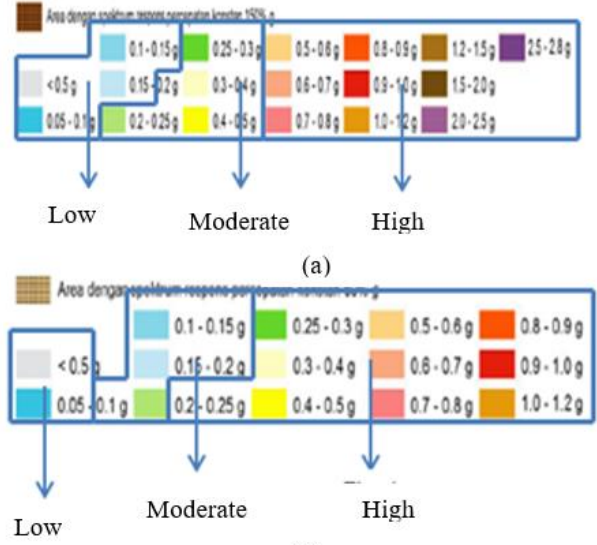

(b)

Figure 2. Determination of the earthquake area; $\quad$ (a) 0.2 second, (b) 1.0 second $[1,2]$

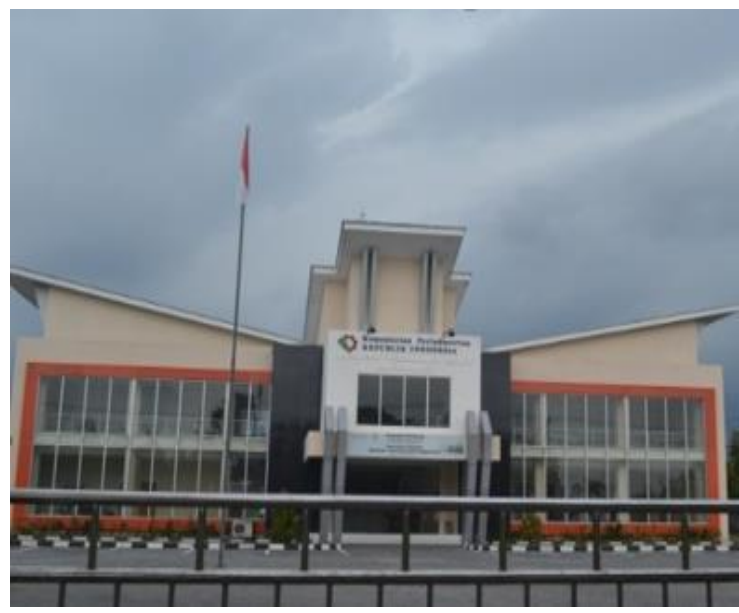

Figure 3. Front view of ATK Academy building

An example on the method to analyse the Administration building of the ATK Academy with RVS method presents in this paper. The administration building of the ATK Academy and its sketch and front view can be seen in Figures 3 and 4 respectively. Table 2 shows the filling of the RVS form of the Administration building of the ATK Academy. The full paper should be written in English.

The RVS analysis of the building is explained as

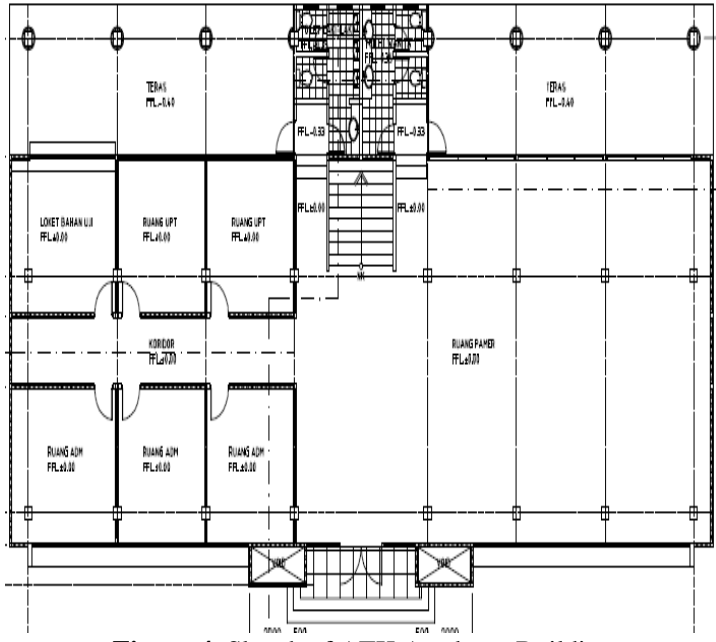

Figure 4. Sketch of ATK Academy Building

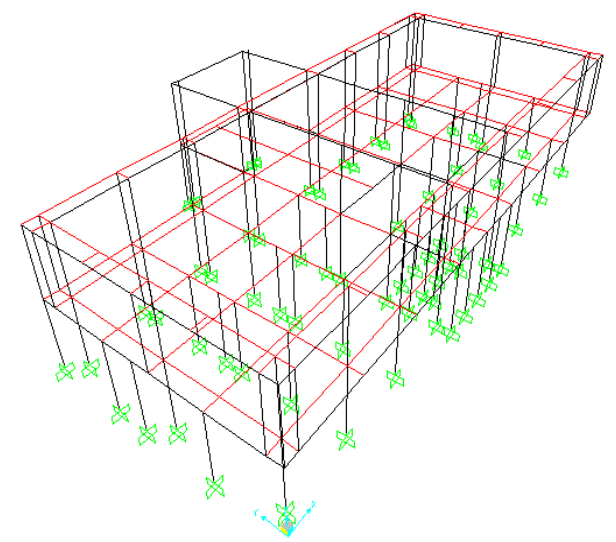

Figure 5. Model of ATK Academy building

follows:

1. Fill in the building information, building plan sketch and picture. Fill in the information about the building's function (school), soil information (Stiff soil, D), building's capacity (101-1000) and structures type (Concrete MRF, C1).

2. Fill in the basic score (2.5) and modified score (-0.5; $+1.4 ;-0.6)$, which are determined to get the final 
score of the building, i.e. 2.8. It means that the building is safe based on FEMA 154.

After the process of analysis of ATK building above is finished, then it is continued to other buildings, which are the the Dormitory building of Ministry of Internal Affair; the Office building of Department of Agriculture; the Educational building of Polytechnics of Health. The result shown on Table 3.

\section{Numerical Analysis of the buildings}

All buildings used as the RVS case study in Yogyakarta also controlled against earthquake loading based on SNI 1726. The 3-dimensional building model was analysed using SAP 2000. The results of analysis of the structures must be controlled to a certain limitation in accordance with SNI 1726 rules for determining the eligibility of the structural system. The controlled of SNI 1726 are as follows:

- Control of mass participation,

- Control of vibrating period,

- Control of final value of response spectrum,

- Control of drift.

The administration building of the ATK Academy is given here as an example of the numerical analysis [5]. The model of the building using SAP2000 can be seen in Figure 5. After inputting the geometry and material properties, the dead, live and earthquake loads were inputted based on the building location and function.

The control of mass participation from the building is $97.0 \%$ at the $\mathrm{X}$ direction in the mode to 3 , and $96.28 \%$ at $\mathrm{Y}$ directions in the mode to 1 . It can be concluded that the structural analysis has been done already eligible to SNI 1726 article 7.9.1 which the mass participation is at least $90 \%$.

The period of the structure is

$\mathrm{T}=\mathrm{Ct} . \mathrm{hnx}=0.3028 \mathrm{~s}$

Where, $\mathrm{Ct}$ is 0.0466 , hn is 8 meters and $\mathrm{x}$ is 0.9 .

The value of $\mathrm{Cu} \times \mathrm{T}=1.4 \times 0.309306=0.4239 \mathrm{~s}$.

The period of structure from the numerical analysis is $0.41811 \mathrm{~s}$, it is smaller than the value of $\mathrm{Cu} \times \mathrm{T}$. Thus the structural analysis of the ATK Academy building is eligible based on SNI 1726, Article 7.8.2.

The final value of the dynamic response of building structures in the specified direction could not be less than $85 \%$ of the static response. After analysis of the building model, the base forces of the building are less than $85 \%$ of the static response, thus it should be enlarged by scale factor to qualify of the SNI 1726.
The allowable drift of the building based on SNI 1726 is $100 \mathrm{~mm}$. The actual drifts of the building at the first and second floors in X direction are $17.04 \mathrm{~mm}$ and $10.97 \mathrm{~mm}$, respectively. The drifts at the first and second floors in $Y$ direction are $20.77 \mathrm{~mm}$ and $14.35 \mathrm{~mm}$, respectively. Thus it can be said that the building is eligible for the drift control.

The three other buildings were analysed to find out the control qualification based on the SNI 1726. The result is that all of the buildings are safe against earthquakes.

\section{E. Comparison}

The comparison between the results of the RVS method and the control of SNI 1726 can be seen in Table 4. It can be said that all the buildings are adequate of the RVS method of FEMA 154 and SNI 1726.

\section{CONCLUSION}

Based on the result of this study, it can be concluded that:

1. The modifier scores that must be noted are the post-benchmark and the vertical irregularity because the both scores influence more on the final structural score of the building.

2. When applying RVS for Indonesian seismic map, it should be noted that the earthquake acceleration from FEMA 154 and SNI 1726 in order to avoid mistakes in determining earthquake zone.

3. All buildings that used as a case study are concluded that the buildings are safe from earthquake either by RVS method or structural analysis using SNI 1726.

\section{REFERENCES}

[1] ATC, 2002, Rapid Visual Screening of Buildings for Potential Seismic Hazards: A Handbook (2nd edition), prepared by the Applied Technology Council for the Federal Emergency Management Agency, FEMA 154 Report, Washington D.C.

[2] Badan Standardisasi Nasional, 2012, "Tata Cara Perencanaan Ketahanan Gempa Untuk Struktur bangunan Gedung dan Non Gedung", SNI 1726, Jakarta.

[3] Alfia, F., Aji, P and Wahyuni, E, 2014, "Studi Literatur Rapid Visual Screening untuk Mengetahui Potensi Kerentanan Bangunan Terhadap Bahaya Gempa". Jurnal Teknik POMITS volume 1, Number 1.(2014)1-6.

[4] ASCE, 1998, Handbook for the Seismic Evaluation of Buildings - A Pre-standard, prepared by the American Society of Civi Engineers for the Federal Emergency Management Agency, FEMA 310 Report, Washington D.C.

[5] Wahyuni, E and Tethool, Y, 2015, "Effect of vierendeel panel width and vertical truss spacing ratio in staggered truss framing system under earthquake loads". International Journal of Civil Engineering, Volume 13, Number 2, p. 213-221. 